\title{
Trust and Trustworthiness of Immigrants and Native-Born Americans*
}

\author{
James C. Cox \\ Noah Langdale Jr. Eminent Scholar Chair \\ Experimental Economics Center and Department of Economics \\ Georgia State University \\ 14 Marietta Street NW, Atlanta, GA 30303 \\ Email: jccox@gsu.edu \\ Wafa Hakim Orman \\ Assistant Professor \\ Department of Economics, Accounting, and Finance \\ University of Alabama in Huntsville \\ 301 Sparkman Drive, Huntsville AL 35899 \\ Email: wafa.orman@uah.edu
}

\begin{abstract}
Trust and trustworthiness are crucial to amelioration of social dilemmas. Distrust and malevolence aggravate social dilemmas. We use an experimental moonlighting game with a sample of the U.S. population, oversampling immigrants, to observe interactions between immigrants and native-born Americans in a social dilemma situation that can elicit both benevolent and malevolent actions. We survey participants in order to relate outcomes in the moonlighting game to demographic characteristics and traditional, survey-based measures of trust and trustworthiness and show that they are strongly correlated. Overall, we find that immigrants are as trusting as native-born U.S. citizens when they interact with native-born citizens but do not trust other immigrants. Immigrants appear to be less trustworthy overall but this finding disappears when we control for demographic variables. Women and older people are less likely to trust but no more or less trustworthy. Highly religious immigrants are less trusting and less trustworthy than both other immigrants and native-born Americans.
\end{abstract}

Keywords: experiment, trust, trustworthiness, religiosity, immigrants, native-born

* This research was supported by the NSF-supported Time-Sharing Experiments in the Social Sciences (TESS). We are grateful to Knowledge Networks, Inc. for conducting the experiment and to referees for helpful comments and suggestions. 


\section{Introduction}

Trustworthiness of immigrants is an important political and security question. Trust in immigrants by native-born citizens is important for acceptance of immigrants' participation in mainstream economic activities in their adopted country. The central purpose of this study is to elicit data on trust and trustworthiness between first-generation immigrants and native-born Americans. For comparison, we also elicit data on trust and trustworthiness among immigrants and among natives.

We use an experimental moonlighting game (Abbink et al., 2000; Cox, et al., 2008b) to study behavior in a social dilemma situation and pair native-born Americans with firstgeneration immigrants. We chose the moonlighting game for our experiment rather than the investment (or trust) game (Berg et al., 1995; Glaeser et al., 2000; Carter and Castillo, 2002; Cox, 2004) because it allows first movers and second movers to both give and take money. It thereby makes possible observation of behavior with both positive motivations (such as altruism, trust and trustworthiness) and negative motivations (such as malevolence, distrust and untrustworthiness).

Pew Research (2013) found that in terms of educational attainment, incomes, poverty rates, and many other characteristics, second generation immigrants to the United States closely resembled the full U.S. adult population. Rumbaut (2004) also foundinds significant evidence of second and third-generation immigrants moving closer to the U.S. population mean in terms of English proficiency, education levels, and occupational attainment. We therefore consider second-generation immigrants as native-born Americans for the purposes of this study.

We combine the experiment with a survey to provide more data. The survey includes selected core questions from the World Bank's questionnaire on social capital (Grootaert et al., 2004) as well as questions about demographic characteristics, income, education, life experiences, religious attendance, and membership in secular organizations. We examine the relationship between survey responses and experimental behavior.

The experiment was conducted online by Knowledge Networks, a survey research firm. Subjects were randomly selected from the Knowledge Networks panel, which is a representative 
sample of the American population. Our use of a random population sample of subjects, rather than student subjects, increases the representativeness of our findings. We oversampled immigrants for the purposes of this study.

\section{Game and Experiment Setup}

\section{$\underline{2.1 \text { Game Form and Beliefs Elicitation }}$}

The setup of the game is as follows. Each individual is randomly assigned to being either a first mover or a second mover. Each first and second mover is credited with a money endowment of $\$ 10$. Each first mover is given the task of deciding whether she wants to give to a randomly paired second mover none, some, or all of her $\$ 10$ endowment or take up to $\$ 5$ from the paired person's endowment. Any amounts given by the first mover are tripled by the experimenter, while any amounts taken by the first mover are not transformed. The second mover then decides how much to return to the first mover, and can also punish the first mover. If the first mover sends the amount $F \geq 0$, the second mover's endowment increases to $\$ 10+\$ 3 F$. If the first mover takes the amount $\mathrm{F}<0$, the second mover's endowment becomes $\$ 10-\$|\mathrm{~F}|$. The second mover decides whether to reward or punish the first mover. If the second mover rewards the first mover, she reduces her own payoff by $\$ 1$ for each $\$ 1$ that she increases the payoff of the first mover. If the second mover punishes the first mover, she reduces her own payoff by $\$ 1$ for each $\$ 3$ that she decreases the payoff of the first mover. The second mover's choices are constrained so as not to give either person a negative payoff. All choices are required to be in integer amounts.

The total payoff of a pair of first and second movers is maximized when the first mover sends his entire $\$ 10$ endowment to the second mover; that choice increases the total payoff of a pair of subjects from the endowed amount of $\$ 20$ to the maximum amount of $\$ 40$. The first mover may send a positive amount to the second mover because of altruistic preferences or trust that the second mover will share the profits generated by the experimenter's tripling of amounts sent or because of both motivations. A second mover may return a positive amount to the first mover because of altruistic preferences or positive reciprocity to the generous action of the first mover or because of both motivations (Cox, et al 2008b). If a first mover has self-regarding (homo economicus) preferences and believes that second movers also have such preferences, the 
first mover will take the maximum amount of $\$ 5$ from the second mover. A second mover with self-regarding preferences will neither punish nor reward a first mover because either of such actions cost the second mover money. Hence the subgame perfect equilibrium of the moonlighting game for a pair of agents with self-regarding preferences (and beliefs that the other has self-regarding preferences) is for the first mover to take $\$ 5$ and the second mover to neither punish nor reward (i.e. choose the amount 0). A second mover, however, may not have selfregarding preferences; instead a second mover may be positively reciprocal towards a second mover who sends money and negatively reciprocal to a first mover who takes money (as modeled, for example, in Cox et al 2008a). If a first mover takes $\$ 5$, which reduces the second mover's endowment from $\$ 10$ to $\$ 5$, a negatively reciprocal or malevolent second mover may respond by spending her remaining $\$ 5$ in order to take $\$ 15$ from the first mover. In that event, the pair of subjects in this game has a total payoff of $\$ 0$.

In summary, the range of payoffs to a pair of subjects from more or less successful resolution of the social dilemma in the moonlighting game varies from $\$ 40$ to $\$ 0$. A cooperative pair of subjects can add (as much as) \$20 in profit to their initial endowment of \$20 while an uncooperative pair of subjects can destroy (as much as) the entire \$20 endowment. The moonlighting game is particularly well-suited for researching interactions between immigrants and native-born citizens because it makes possible elicitation of a full range of both positive motivations (such as altruism, trust and trustworthiness) and negative motivations (such as malevolence, distrust and untrustworthiness).

\subsection{Experimental Design and Protocol}

Respondents completed their questionnaires online at their convenience. Due to the nature of the survey, the strategy method (Falk et al., 2008) is the only feasible way to elicit responses from the second mover. The first mover indicates how much they wish to send or take. Each second mover decides, for each possible action of the first mover, whether she wants to give money to the paired first mover or take money from her. This has the added advantage of providing a full range of information on the second mover's responses to each possible decision by the first mover. First and second mover responses were randomly matched ex-post.

Following Dufwenberg and Gneezy (2000), beliefs about the behavior of the average 
person were elicited from both the first movers and the second movers with a monetary reward for guessing correctly. Gächter and Renner (2010) show that incentivized beliefs are more accurate than beliefs that are elicited without a monetary incentive. First movers were asked to guess the behavior of the average second mover and second movers were asked to guess the behavior of the average first mover. This provides more information about their motivations and helps to distinguish between trust in anticipation of reciprocity (or reciprocity in response to trust) versus unconditional altruism.

There are four types of pairings. Using I to represent an immigrant, N to represent a U.S. native, FM to represent the first mover and SM to represent the second mover, the pairings are: I (FM) - I (SM), I (FM) - N (SM), N (FM) - I (SM), and N (FM) - N (SM). The pairings were arranged using the respondents' place of birth, which had been previously collected by Knowledge Networks. Subjects were randomly assigned to treatments and to first mover or second mover role.

Subjects were informed whether the person they were going to be matched with was a U.S. native or an immigrant to the United States. For example, if a respondent who listed their own or their parents' place of birth as Jordan was pre-assigned to the I (FM) - I (SM) treatment they were informed that they would be matched with another randomly selected individual from the Middle East, living in the U.S. If they were assigned to the I (FM) - N (SM) or the N (FM) I (SM) treatment, they were informed that they would be matched with a randomly selected native-born American. A respondent listing their and their parents' place of birth as the U.S. was informed that they would be matched with a randomly selected immigrant if they were assigned to the I (FM) - N (SM) or N (FM) - I (SM) treatment, or with a randomly selected native-borm American if they were assigned to the N (FM) - N (SM) treatment. Immigrants from any particular region were matched only with others from their own region in the I (FM) - I (SM) treatment. While interactions between different immigrant groups are an important topic of study, it is beyond the scope of this paper. Native-born Americans paired with immigrants were informed only of that fact; they were not informed about the country of origin of the immigrant. While (some or many) native-born Americans may discriminate between immigrants from different countries, study of that topic is beyond the scope of the present paper. Our focus is on the dichotomy, native-born vs. immigrant. Study of discrimination between immigrant groups 
would require different treatment cells than we used and use of a subject sample size much larger than the 450 subjects in our study. Information about respondents' religion was not used to match subjects.

Data on income and educational background were collected in the standard set of demographic questions that preceded the survey. We also included selected core questions from the World Bank's questionnaire on social capital (Grootaert et al., 2004) to test if answers to these questions are predictors of behavior in the moonlighting game. The survey included questions on whether the subject or anyone they knew had ever been a victim of a hate crime or prejudice, to ascertain whether these experiences made a person more or less likely to send money, take money, reward, or punish. In these ways, the survey together with the experiment provides a chance to see not just whether people punish or take money, but who does so, with respect to income, background, and life experiences.

The experiment was conducted online by Knowledge Networks. There were 450 subjects, who were a random sample of the Knowledge Networks panel except that immigrants were oversampled. Since the experiment was played as a one-shot game, this implies that there were 225 unique subject pairs and 225 independent observations. Panel registrants had been given the hardware required to complete surveys online using their TV sets. They were all paid based on the outcomes of the moonlighting game. There was no separate participation fee; all panelists were already compensated by Knowledge Networks for being on the panel. The average first mover earned $\$ 20.42$ from the experiment and $\$ 2.87$ as a bonus for the incentivized belief elicitation. The average second mover earned $\$ 26.20$ from the experiment and $\$ 2.07$ as a belief elicitation bonus. Subjects received these payments over and above their normal participation fee. Subject instructions and the full list of survey questions are available online at: http://tinyurl.com/a58t6hw.

\section{Results}

We separately identify the differences in behavior within immigrant and native-born communities, as measured by the I (FM) - I (SM) and N (FM) - N (SM) treatments, and between immigrant and native communities, as measured by the I (FM) - N (SM) and N (FM) - I (SM) 
treatments. We aim to identify the demographic and other characteristics that make immigrants more or less likely than native-born Americans to give money, take money, reward, or punish. Subjects were randomly assigned to treatments. The numbers of subjects in each treatment cell are shown in Table 1. Table 2 shows the distribution of immigrants by region.

\section{INSERT TABLE 1 ABOUT HERE}

\section{INSERT TABLE 2 ABOUT HERE}

\subsection{Statistical Tests}

Figure 1 shows the average amounts sent by first movers in the various treatments and the proportions of first movers who take money in the four treatments. A Kruskal-Wallis test of equality of distributions shows that the distributions of the amounts sent by first movers and the proportions of first movers who take money are significantly different across the four treatments (p-value $=0.037$ for both).

\section{INSERT FIGURE 1 ABOUT HERE}

A Mann-Whitney test provides support for what seems apparent from a visual inspection of Figure 1: amounts sent by first movers in the Immigrant-Immigrant (I-I) treatment are significantly different from all the others, pooled, at the $5 \%$ level ( $\mathrm{p}$-value $=0.047$ ), and different from the Immigrant-Native $(\mathrm{I}-\mathrm{N})$ treatment at the $10 \%$ level $(\mathrm{p}$-value $=0.077)$. Similarly, first movers in the I-I treatment are significantly more likely to take money from the second mover relative to all other treatments ( $\mathrm{p}$-value $=0.005)$ and even relative to the I-N treatment $(\mathrm{p}$-value $=$ 0.012). Immigrants are less generous towards other immigrants than towards native-born Americans. If we compare immigrant and native-born Americans as first movers facing an immigrant second mover, the native-born Americans send more ( $\$ 2.38$ vs. \$1.14) but this difference is not significant ( $\mathrm{p}$-value is 0.15 ). When paired with a native-born American as a second mover, the amounts sent by immigrant first-movers are not significantly different from amounts sent by native-born Americans ( $\mathrm{p}$-value $=0.90$ ). Immigrant first movers send more when facing native-born second movers than when facing immigrant second movers $-\$ 2.56$ versus $\$ 1.14(p$-value $=0.07)$, and are also significantly more likely to take money from an 
immigrant second mover than a native-born second mover ( $\mathrm{p}$-value $=0.08$ ). Conversely, the amounts sent by native-born American first movers are not significantly different between the Native-Native $(\mathrm{N}-\mathrm{N})$ and Native-Immigrant $(\mathrm{N}-\mathrm{I})$ treatments $(\mathrm{p}$-value $=0.65)$.

It also appears that levels of "complete trust" are lowest in the I-I treatment. $18.2 \%$ of first movers in the N-N treatment send the maximum amount of $\$ 10.18 .03 \%$ of first movers in the I-N treatment, $16.4 \%$ of first movers in the N-I treatment, and $7.14 \%$ of first movers in the I-I treatment send the maximum amount. The I-I treatment is marginally significantly different from all the others for observation of the maximum amount sent by first movers; the p-value from a Mann-Whitney test is 0.096 .

Beliefs elicited with the survey are good predictors of behavior by first movers in the experiment. The Spearman's rank correlation between the amount the first mover sends and what the first mover believes the second mover will return is significant, with a p-value of 0.00 $($ Spearman's rho $=0.3585)$.

Figure 2 depicts the amount that second movers return for each possible amount sent by first movers in each treatment. A Kruskal-Wallis test shows that the amounts returned by second movers for each possible amount sent were significantly different between the four treatments $(\mathrm{p}$-value $=0.0001)$

\section{INSERT FIGURE 2 ABOUT HERE}

Unless otherwise specified, all subsequent p-values reported are from Mann-Whitney tests. Trustworthiness appears to be lowest in the N-I treatment. $70.2 \%$ of second movers in the $\mathrm{N}-\mathrm{N}$ treatment return at least the same amount that the first mover sent them. $65.4 \%$ of second movers in the I-N treatment, $62.8 \%$ of second movers in the I-I treatment, and $59.7 \%$ of second movers in the N-I treatment return at least the amount sent by the first mover. The N-N and N-I treatments are significantly different from pooled data for all the others (p-values are 0.00 for both). Looking at treatments individually, the N-I treatment is significantly different from the N$\mathrm{N}$ treatment $(\mathrm{p}$-value $=0.00)$ and the I-N treatment $(\mathrm{p}$-value $=0.008)$ but not the I-I treatment $(\mathrm{p}$ value $=0.2$ ). The $\mathrm{N}-\mathrm{N}$ treatment is also significantly different from the I-N treatment ( $\mathrm{p}$-value = $0.026)$ and the I-I treatment (p-value $=0.00)$. 
The pattern of results we observe does not conform to subjects' discriminating according to an in-group, out-group dichotomy for native-born and immigrant subjects. The native-born subjects do not cooperate less with immigrants in resolving the social dilemma in the moonlighting game. Inconsistency for immigrant behavior is not as clear because in the I-I treatment immigrants were paired with other immigrants from the same region but not from the same specific country of origin.

As shown in Figure 3, we find that the first and second movers' beliefs do not actually vary significantly between treatments based on whether the first and second movers do or do not belong to the same immigrant or native category. Although beliefs are lowest in the I-I treatment, this difference is not statistically significant. It appears that people send in an expectation of positive reciprocity but also out of a fear of negative reciprocity. The people who take money are more likely to believe that the second mover will return a lower amount (p-value $=0.00)$.

\section{INSERT FIGURE 3 ABOUT HERE}

Nee and Sanders (2001) discuss the complex feelings that immigrants have towards their communities and the enclaves they find themselves in. They rely on other members of their own ethnic group extensively but are also apprehensive about their own dependence on them and sometimes afraid of being taken advantage of. This in turn may lead to significantly lower trust or altruism towards other immigrant communities and immigrants in general, which may be perceived as insular enclaves of their own.

The different behavior of immigrants than natives can result from both the "immigrant experience" and the characteristics of those subsets of foreign communities that self-select into

emigration. An empirical study designed to disentangle these separate effects would necessarily involve paired experiments in the U.S. in a very large number of immigrant communities of origin.

Looking back at Figure 2, we examine the amounts returned by second movers, on average, for each possible amount sent by first movers. Immigrant second movers return $\$ 3.13$ on average across all possible first mover amounts; they return less than native-born Americans, 
who return $\$ 3.92$ on average ( $\mathrm{p}$-value $=0.00$ ). There is no significant difference, however, between what immigrant second movers return to native-born Americans and what they return to other immigrants $(\mathrm{p}$-value $=0.2)$.

\subsection{Results for Hypothesis H3}

The survey elicits membership in various types of voluntary associations, including religious, ethnic, professional, and neighborhood groups, which we use to measure social capital. We find that almost $42 \%$ of our subjects do not belong to any voluntary association, and that “non-joiners" are significantly more likely to take money as first movers: $29.8 \%$ of them do, as compared to $16.4 \%$ of those who belong to at least one voluntary association (p-value $=0.018$ ). $31.8 \%$ of native-born "non-joiners" take money from a native-born second mover, and $26.9 \%$ take money from an immigrant second mover (p-value $=0.7$ ). 26.7\% of immigrant "nonjoiners" take money from a native-born second mover, while $37.5 \%$ take money from an immigrant second mover ( $\mathrm{p}$-value $=0.45$ ). Therefore, while non-joiners are more likely to take money, this does not appear to be affected by whether or not the second mover belongs to the same immigrant or native category as the first mover.

\section{INSERT TABLE 3 ABOUT HERE}

As is clear from Figure 4 and columns 1 and 2 of Table 4, immigrant first movers who do not belong to any voluntary association are more likely to take money, and send significantly less than those who belong to at least one ( $p$-value $=0.04$ ). Second movers who do not belong to any association return less on average for each possible amount the first mover can send; they return $\$ 3.23$ on average as compared to $\$ 3.80$ for those who belong to at least one association (p-value $=0.007)$.

\section{INSERT FIGURE 4 ABOUT HERE}

Religious attendance is another personal characteristic that may affect trust and trustworthiness. Garcia-Muñoz and Neuman (2012) survey the literature on whether religiosity serves as a bridge (increasing assimilation) or buffer (preventing assimilation) for immigrants, and describe a large body of literature arguing for both. They find some evidence that "bridging" 
dominates in the U.S. while "buffering" dominates in Europe, but they do not explicitly examine the effects of differential levels of attendance within immigrant communities. Figure 5 shows distributions over levels of religious attendance of amounts sent or taken by immigrant and native-born first movers in our experiment. Immigrants who attend more than once a week take on average $\$ 1.45$ from the second mover while those who don't attend more than once per week send $\$ 2.39$ on average $(\mathrm{p}$-value $=0.02)$. Native-born first movers who attend more than once a week send $\$ 2.42$ on average, in contrast to the taking behavior by highly religious immigrants $(\mathrm{p}$-value $=0.036)$.

\section{INSERT FIGURE 5 ABOUT HERE}

Immigrant second movers who attend more than once a week return $\$ 2.62$ less than all other immigrant second movers ( $\mathrm{p}$-value $=0.00)$, and $\$ 3.35$ less than immigrants who attend once a week ( $p$-value $=0.00)$. Native-born second movers who attend more than once a week, on the other hand, return $\$ 0.23$ less than all other native-born second movers ( $\mathrm{p}$-value $=0.9$ ) and $\$ 0.97$ more than native-born second movers who attend once a week ( $\mathrm{p}$-value $=0.11$ ). Additionally, native-born second movers who attend more than once a week return, on average, $\$ 3.46$ more than immigrants who attend more than once a week $(p$-value $=0.00)$. Very high religious attendance among immigrants is associated with lower levels of the sort of generic trust and trustworthiness that our experiment measures. At the same time, immigrants who attend weekly (as opposed to more than once weekly) send \$2.05 less as first movers than native-born first movers who attend weekly ( $\mathrm{p}$-value $=0.12$ ), but behave no differently as second movers ( $\mathrm{p}$ value $=0.6$ ). Our results do not allow us to infer causality; it may be that very high religiosity reduces trust and trustworthiness with respect to broader society, or it may be that those less inclined to trust the broader population seek comfort in religion to a greater extent than most. Utilizing the "community" versus "society" (Gemeinschaft/Gesellschaft) framework originally developed by Tönnies (1957), one might argue that the immigrants who attend religious services more than once weekly are seeking the comfort and solace of their community and do not trust, or have chosen to reduce their relationships or interactions with, broader society.

Glaeser et al. (2000) reported that standard survey questions about trust predicted second mover behavior but not first mover behavior in their trust game. From responses to the question: 
"On a scale of 1 to 5, do you believe that most people can be trusted (1), or that you can't be too careful in dealing with people (5)", we normalize the responses and construct a Z-score to measure trust. We also create a "trusting" indicator which equals one if the individual responds with either 1 or 2 .

Answers to the survey question about trust are predictors of both first and second mover behavior in the moonlighting game. On average first movers who respond with a 1 or 2 send more $(\mathrm{p}$-value $=0.078)$ and second movers who respond with a 1 or 2 return more $(\mathrm{p}$-value $=$ 0.043). Trust question answers are not significantly different between subjects who were randomly assigned to be first movers or second movers. However, immigrants report being significantly less trusting: $26.5 \%$ answered the trust question with a 1 or 2 as compared to $37.7 \%$ of native-born Americans ( $\mathrm{p}$-value = 0.012). The difference between our results and those of Glaeser et al. (2000) may be due to our use of the moonlighting game rather than the trust game, or it may be due to our use of a random population sample rather than undergraduate student subjects.

Being a victim of a hate crime may potentially color one's perceptions of the group that the perpetrator belongs to, or it may reduce trust in broader society. First movers who responded that they or someone they knew had been victims of a hate crime actually sent $\$ 2.25$ more than those who did not (p-value $=0.015$ ). However, immigrants who had been victims of a hate crime returned $\$ 1.20$ less on average as second movers $(p$-value $=0.013)$, while it did not affect the behavior of native-born second movers. $10.4 \%$ of immigrants and $12 \%$ of native-born Americans answered that they personally had been victims of a hate crime, while $15.6 \%$ of immigrants and $19.2 \%$ of native-born Americans responded that someone they knew had been a victim of a hate crime. There was no significant difference between first and second movers. This is true even when we look exclusively at immigrants.

\section{$\underline{3.3 \text { Regression Results }}$}

We hypothesize that the amount sent by the first mover in a pair $i$ is a function of their belief about the second mover's action and their own characteristics:

$$
S_{i}=f\left(X_{1 i}, \chi_{1 i}, \pi_{12 i}\right)+e_{i}
$$


where $S_{i}$ is the amount the first mover sends, $X_{1 i}$ is a vector of observed individual characteristics, $\chi_{1 \mathrm{i}}$ is a vector of unobserved individual characteristics, and $\pi_{12 i}$ represents the first mover's belief about the second mover's action. Similarly, the amount returned by the second mover for each level of $S$ is a function of their individual characteristics and their beliefs about the first mover:

$$
R_{i S}=f\left(X_{2 i}, S, \chi_{2 i}, \pi_{21 i}\right)+e_{i}
$$

where $R_{i S}$ refers to the amount the second mover returns for a given level of $S$, the amount sent by the first mover.

Table 4 reports estimates of the determinants of amounts sent by first movers and amounts returned by second movers. There are fewer than 225 subjects in the first and secondmover regressions in columns (1) and (3) because some subjects did not complete the entire questionnaire. We see that women and older people are less likely to send positive amounts. Interestingly, the amount that the first mover believes the second mover will return is less important than the belief that the second mover will return some positive amount.

\section{INSERT TABLE 4 ABOUT HERE}

Ex ante, one might expect education to make people more cooperative. We find that, controlling for other factors, education does not seem to increase amounts sent by first movers although it does increase amounts returned by second movers (column 3 , Table 4). ${ }^{1}$

Religious attendance makes immigrants less likely to trust or be altruistic, but does not affect trustworthiness, partially corroborating results reported above. In each case we see that those who do not belong to any voluntary association at all are significantly less trusting or altruistic, but no less trustworthy. The moonlighting experiment is therefore able to capture an important element of cooperative behavior. For all second movers, those with a higher level of belief about the amount the first mover will send return higher amounts - their optimism appears to translate

${ }^{1}$ Since income and education are positively correlated, we also ran the regressions with only income or only education as robustness checks. Dropping one lowers the p-value on the other for the regression in column 3, but does not change any of the other results. Neither income nor education is significant in any of the other regressions, whether included together or separately. 
to higher levels of trustworthiness.

Columns 2 and 4 of Table 4 look exclusively at immigrants and corroborate our earlier findings that as first movers they are less generous towards other immigrants than towards native-born Americans. However, there are no significant differences in their trustworthiness regardless of whether the first mover is another immigrant or not. There are strong regional effects, with immigrants from the Middle East and South Asia being the least trustworthy and those from East Asia and the Caribbean being more generous as first movers. Immigrants who reported having been victims of a hate crime were less trustworthy.

\section{Concluding Remarks}

Some major findings stand out from all the results. Reported beliefs predict first movers' actions: rank correlation between amounts first movers send and their reported beliefs about the amounts second movers will return is highly significant. Immigrants are treated less generously than native-born Americans, particularly by other immigrants. While at first glance immigrants appear less trustworthy, when we control for demographic variables and the amount sent by the first mover this is no longer the case. Immigrants who do not belong to any voluntary associations are less cooperative than other immigrants.

An intriguing new finding was made possible by use of the moonlighting game, which allows taking as well as giving, and elicitation of level of religious participation, which allows discrimination between modal and high religiosity. We find that, when making the first mover decision, immigrants who attend religious services more than once a week take on average $\$ 1.45$ from the second mover while those who don't attend more than once per week give \$2.39 on average $(p-v a l u e=0.02)$. Immigrant second movers who report being highly religious return $\$ 2.62$ less than immigrants who attend less often $(\mathrm{p}$-value $=0.00)$. The direction of causation is unclear, but high religiosity is strongly associated with failure by immigrants to cooperatively resolve the social dilemma in the moonlighting game. High religious attendance by native-born citizens is not associated with less cooperative behavior. 


\section{References}

Abbink, K., Irlenbusch, B., and Renner, E., 2000. The moonlighting game: An experimental study on reciprocity and retribution. Journal of Economic Behavior \& Organization 42(2), $265-277$.

Berg, J., Dickhaut, J., and McCabe, K., 1995. Trust, reciprocity, and social history. Games and Economic Behavior 10(1), 122-142.

Carter, M. R. and Castillo, M., 2002. The economic impacts of altruism, trust, and reciprocity: An experimental approach to social capital. Wisconsin-Madison Agricultural and Applied Economics Staff Papers 448, Wisconsin-Madison Agricultural and Applied Economics Department.

Cox, J. C., 2004. How to identify trust and reciprocity. Games and Economic Behavior 46(2), 260-281.

Cox, J. C., Friedman, D., and Sadiraj, V. 2008a. Revealed altruism. Econometrica 76(1), 31-69.

Cox, J. C., Sadiraj, K., and Sadiraj, V., 2008b. Implications of trust, fear, and reciprocity for modeling economic behavior. Experimental Economics 11, 1-24.

Dufwenberg, M. and Gneezy, U., 2000. Measuring beliefs in an experimental lost wallet game. Games and Economic Behavior 30(2), 163-182.

Falk, A., Fehr, E., and Fischbacher, U., 2008. Testing theories of fairness - intentions matter. Games and Economic Behavior 62(1), 287-303.

Gächter, S. and Renner, E., 2010. The effects of (incentivized) belief elicitation in public goods experiments. Experimental Economics 13(3), 364-377.

García-Muñoz, Teresa and Neuman, Shoshana, 2012. Is Religiosity of Immigrants a Bridge or a Buffer in the Process of Integration? A Comparative Study of Europe and the United States. IZA Discussion Paper No. 6384.

Glaeser, E. L., Laibson, D. I., Scheinkman, J. A., and Soutter, C. L., 2000. Measuring trust. Quarterly Journal of Economics 115(3), 811-846.

Grootaert, C., Narayan, D., Jones, V. N., and Woolcock, M., 2004. Measuring social capital: An integrated questionnaire.World Bank Working Paper 18, World Bank, Washington, DC.

Nee, V., \& Sanders, J., 2001. Trust in ethnic ties: Social capital and immigrants. Trust in Society 2, 374-392. 
Pew Research. 2013. "Second-Generation Americans: A Portrait of the Adult Children of Immigrants."

Rumbaut, Rubén G. 2004. "Ages, Life Stages, and Generational Cohorts: Decomposing the Immigrant First and Second Generations in the United States.” International Migration Review, volume 38(3).

Tönnies, Ferdinand. 1957. Community and Society. (Charles P. Loomis, Trans.) Michigan State University Press, East Lansing, Michigan. 
Figures

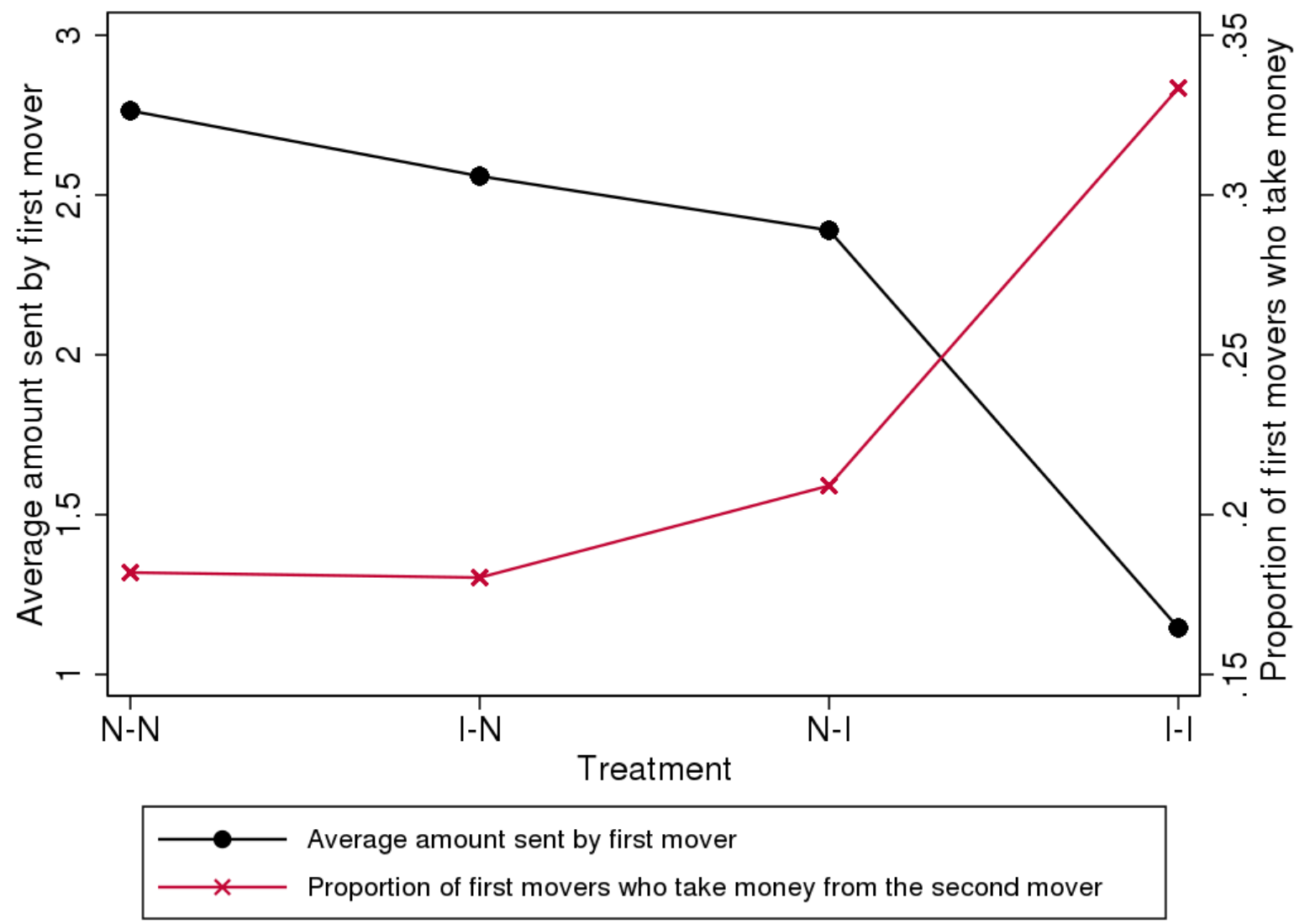

Figure 1: First mover behavior by treatments 


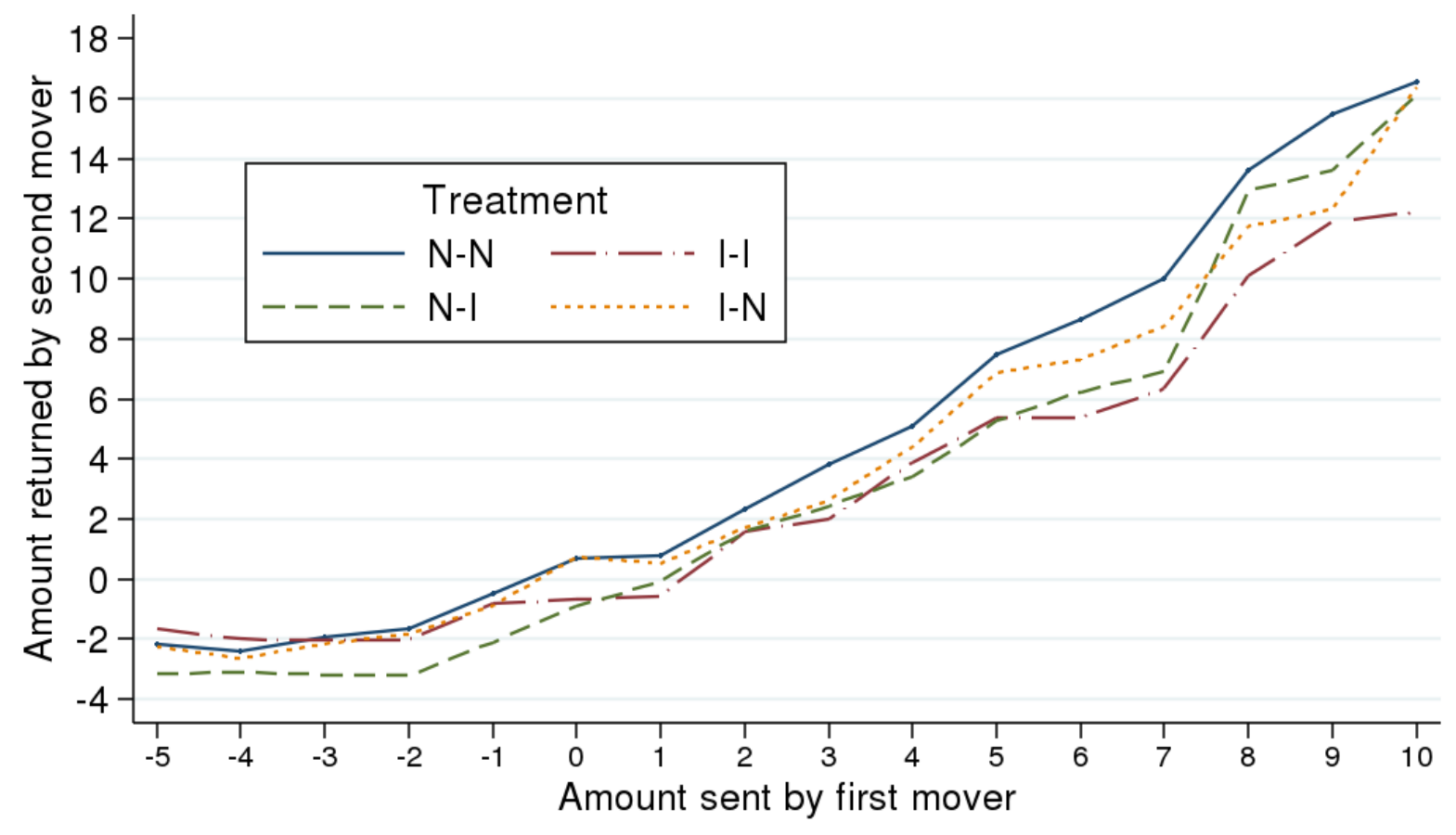

Figure 2: Amount returned by second mover for each level of first mover amount sent by treatments 


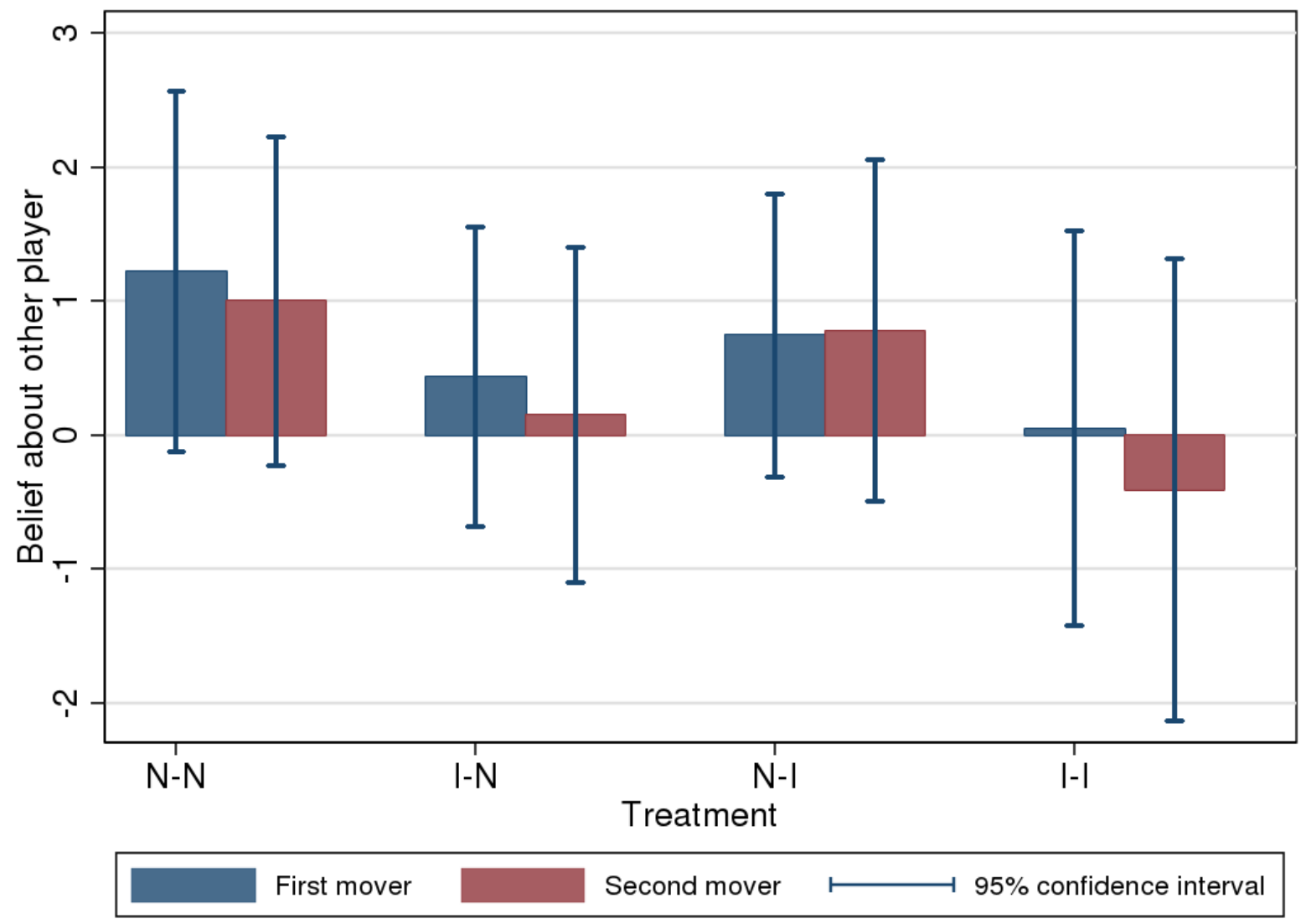

Figure 3: First and second movers' beliefs by treatments 


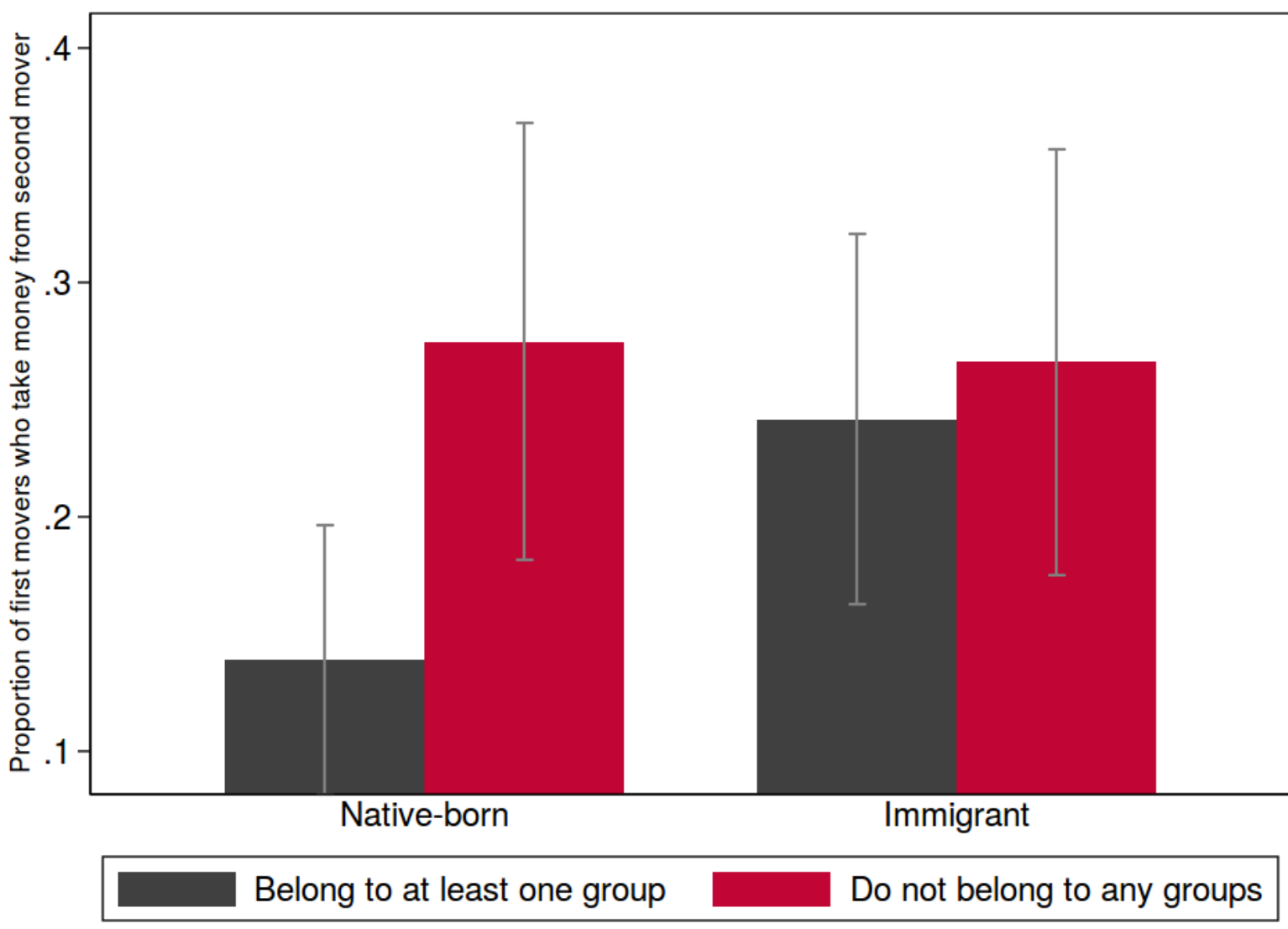

Figure 4: Proportion of first movers who take money across membership in voluntary associations 


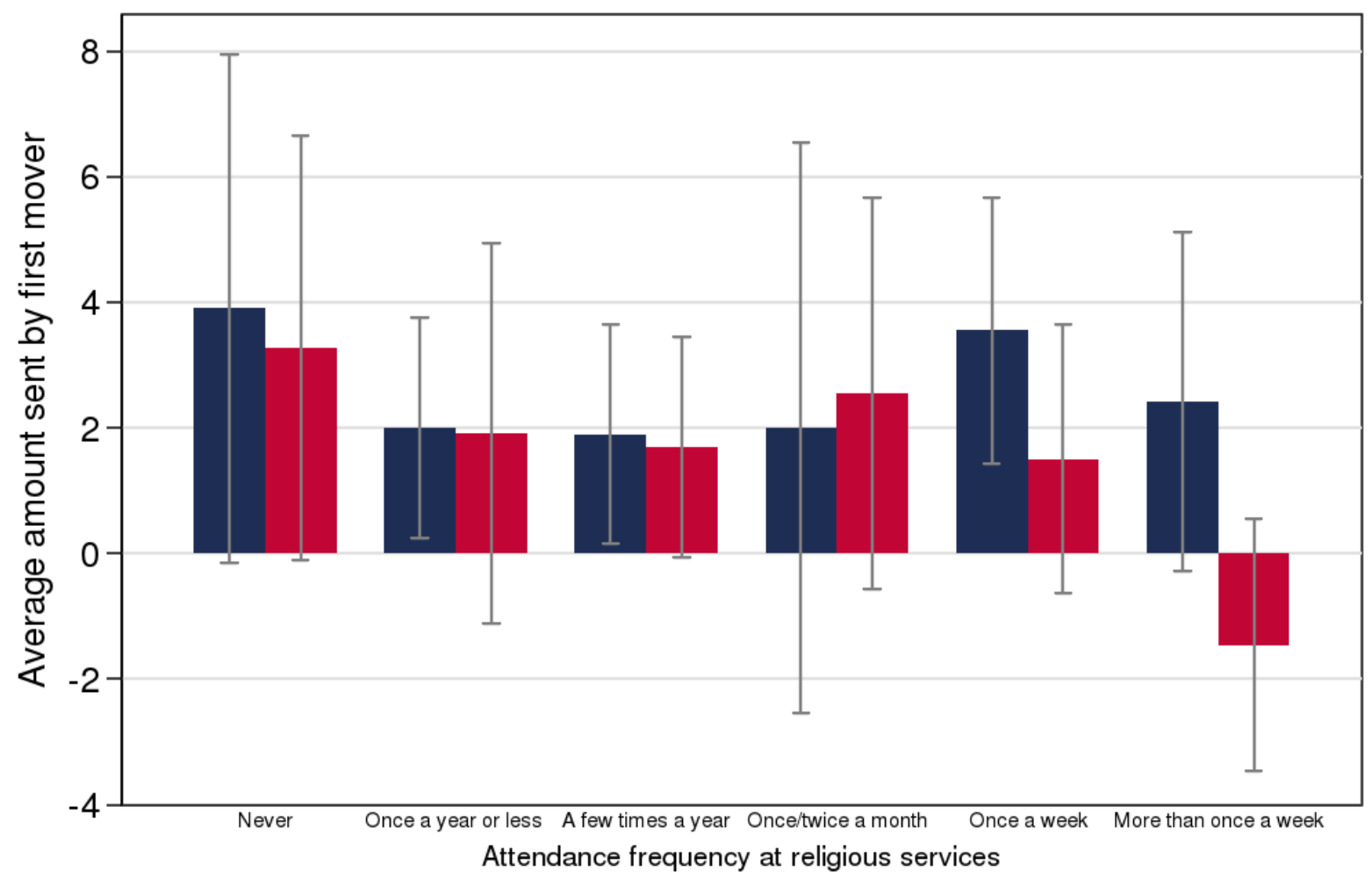

Native-born Immigrant

Figure 5: Average amounts sent (or taken) by first movers across levels of religious attendance 


\section{Tables}

Table 1: Subjects per treatment

\begin{tabular}{lcc}
\hline Treatment & Number & Percent \\
\hline N-N & 110 & $24 \%$ \\
I-N & 122 & $27 \%$ \\
N-I & 134 & $30 \%$ \\
I-I & 84 & $19 \%$ \\
\hline Total & 450 & $100 \%$
\end{tabular}

Table 2: Immigrants by region

\begin{tabular}{lcc}
\hline & Number & Percent \\
\hline Northern/Western Europe & 57 & $27 \%$ \\
Eastern Europe & 10 & $5 \%$ \\
South Asia & 12 & $6 \%$ \\
East Asia & 28 & $13 \%$ \\
South-East Asia & 20 & $9 \%$ \\
Latin America & 35 & $17 \%$ \\
The Caribbean & 9 & $4 \%$ \\
North America & 34 & $16 \%$ \\
Middle East/Central Asia & 7 & $3 \%$ \\
\hline Total & 212 & $100 \%$ \\
\hline
\end{tabular}




\begin{tabular}{|c|c|c|c|}
\hline & Native-born & Immigrant & Total \\
\hline Trade or business association & $4.3 \%$ & $3.3 \%$ & $3.8 \%$ \\
\hline $\begin{array}{l}\text { Professional association (doctors, teachers, } \\
\text { veterans) }\end{array}$ & $17.5 \%$ & $14.8 \%$ & $16.2 \%$ \\
\hline Trade union or labor union & $15.3 \%$ & $8.6 \%$ & $12.1 \%$ \\
\hline Neighborhood committee & $8.1 \%$ & $8.1 \%$ & $8.1 \%$ \\
\hline $\begin{array}{l}\text { Religious or spiritual group (e.g. church, mosque, } \\
\text { temple, etc) }\end{array}$ & $37.9 \%$ & $32.9 \%$ & $35.5 \%$ \\
\hline Political group or movement & $5.1 \%$ & $4.3 \%$ & $4.7 \%$ \\
\hline $\begin{array}{l}\text { Cultural group or association (e.g. arts, music, } \\
\text { theater, film) }\end{array}$ & $7.2 \%$ & $7.6 \%$ & $7.4 \%$ \\
\hline $\begin{array}{l}\text { Education group (e.g. parent-teacher association, } \\
\text { school committee) }\end{array}$ & $12.3 \%$ & $9.1 \%$ & $10.8 \%$ \\
\hline Sports group & $10.6 \%$ & $8.1 \%$ & $9.4 \%$ \\
\hline Youth or student group & $6.4 \%$ & $3.8 \%$ & $5.2 \%$ \\
\hline NGO or civic group (e.g. Rotary Club, Red Cross) & $3.4 \%$ & $1.9 \%$ & $2.7 \%$ \\
\hline Ethnic-based community group & $0.4 \%$ & $4.8 \%$ & $2.5 \%$ \\
\hline Other groups & $3.4 \%$ & $2.9 \%$ & $3.2 \%$ \\
\hline None & $38.7 \%$ & $44.8 \%$ & $41.6 \%$ \\
\hline Total & $100 \%$ & $100 \%$ & $100 \%$ \\
\hline
\end{tabular}


Table 4: Regression Results

\begin{tabular}{|c|c|c|c|c|}
\hline & $(1)$ & $(2)$ & $(3)$ & $(4)$ \\
\hline & FM Amount & $\begin{array}{c}\text { FM Amount: } \\
\text { Immigrants } \\
\text { Only }\end{array}$ & SM Amount & $\begin{array}{c}\text { SM Amount: } \\
\text { Immigrants } \\
\text { Only }\end{array}$ \\
\hline Treatment I-I & $\begin{array}{l}-1.161 \\
(1.066)\end{array}$ & $\begin{array}{c}-1.906 * * \\
(0.887)\end{array}$ & $\begin{array}{c}0.731 \\
(1.744)\end{array}$ & $\begin{array}{c}0.801 \\
(1.001)\end{array}$ \\
\hline Treatment N-I & $\begin{array}{c}0.537 \\
(0.857)\end{array}$ & & $\begin{array}{l}0.0475 \\
(1.615)\end{array}$ & \\
\hline Treatment I-N & $\begin{array}{c}0.566 \\
(1.090)\end{array}$ & & $\begin{array}{l}-0.809 \\
(0.831)\end{array}$ & \\
\hline Female & $\begin{array}{c}-1.368 * * \\
(0.614)\end{array}$ & $\begin{array}{l}-1.217 \\
(0.933)\end{array}$ & $\begin{array}{l}-0.133 \\
(0.629)\end{array}$ & $\begin{array}{l}-0.935 \\
(0.903)\end{array}$ \\
\hline Age & $\begin{array}{c}-0.0527 * * * \\
(0.0198)\end{array}$ & $\begin{array}{l}-0.0487 \\
(0.0355)\end{array}$ & $\begin{array}{l}-0.0373 \\
(0.0237)\end{array}$ & $\begin{array}{l}-0.0760 \\
(0.0517)\end{array}$ \\
\hline Amount FM believes SM will return & $\begin{array}{c}-0.0924 \\
(0.0568)\end{array}$ & $\begin{array}{r}-0.00777 \\
(0.0848)\end{array}$ & & \\
\hline FM belief $>0$ & $\begin{array}{c}3.442 * * * \\
(0.838)\end{array}$ & $\begin{array}{l}2.785^{*} \\
(1.533)\end{array}$ & & \\
\hline FM amount & & & $\begin{array}{l}1.172 * * * \\
(0.0489)\end{array}$ & $\begin{array}{c}1.112 * * * \\
(0.0732)\end{array}$ \\
\hline Amount SM believes FM will send & & & $\begin{array}{c}0.378 * * * \\
(0.132)\end{array}$ & $\begin{array}{c}0.133 \\
(0.184)\end{array}$ \\
\hline SM belief $>0$ & & & $\begin{array}{l}-1.411 \\
(1.124)\end{array}$ & $\begin{array}{l}-0.0367 \\
(1.647)\end{array}$ \\
\hline Income (in '000s) & $\begin{array}{c}-0.00282 \\
(0.00798)\end{array}$ & $\begin{array}{l}-0.0107 \\
(0.0136)\end{array}$ & $\begin{array}{c}0.0112 \\
(0.00756)\end{array}$ & $\begin{array}{c}-0.00676 \\
(0.0111)\end{array}$ \\
\hline Years of schooling & $\begin{array}{c}0.00169 \\
(0.104)\end{array}$ & $\begin{array}{c}0.118 \\
(0.179)\end{array}$ & $\begin{array}{c}0.261 * \\
(0.149)\end{array}$ & $\begin{array}{l}0.0299 \\
(0.174)\end{array}$ \\
\hline Trusting & $\begin{array}{c}0.119 \\
(0.644)\end{array}$ & $\begin{array}{l}-0.640 \\
(0.922)\end{array}$ & $\begin{array}{c}0.565 \\
(0.729)\end{array}$ & $\begin{array}{c}0.704 \\
(1.207)\end{array}$ \\
\hline Religious attendance percentile & $\begin{array}{l}-1.902 \\
(1.251)\end{array}$ & $\begin{array}{c}-8.656^{* * *} \\
(2.028)\end{array}$ & $\begin{array}{c}-0.974 \\
(1.196)\end{array}$ & $\begin{array}{l}0.0723 \\
(1.849)\end{array}$ \\
\hline Catholic & $\begin{array}{c}-4.003 * * * \\
(1.371)\end{array}$ & $\begin{array}{l}-1.947 \\
(1.536)\end{array}$ & $\begin{array}{c}-2.643^{* *} \\
(1.321)\end{array}$ & $\begin{array}{l}-2.900 \\
(2.814)\end{array}$ \\
\hline Baptist & $\begin{array}{c}1.209 \\
(1.748)\end{array}$ & $\begin{array}{l}-2.548 \\
(2.577)\end{array}$ & $\begin{array}{c}1.182 \\
(1.392)\end{array}$ & $\begin{array}{l}-2.806 \\
(2.103)\end{array}$ \\
\hline Protestant (other) & $\begin{array}{c}-2.765 * * \\
(1.389)\end{array}$ & $\begin{array}{l}-0.724 \\
(1.463)\end{array}$ & $\begin{array}{l}-2.548^{*} \\
(1.316)\end{array}$ & $\begin{array}{c}-5.952 * * \\
(2.776)\end{array}$ \\
\hline
\end{tabular}




\begin{tabular}{|c|c|c|c|c|}
\hline & (1) & (2) & (3) & (4) \\
\hline & FM Amount & $\begin{array}{c}\text { FM Amount: } \\
\text { Immigrants } \\
\text { Only }\end{array}$ & SM Amount & $\begin{array}{c}\text { SM Amount: } \\
\text { Immigrants } \\
\text { Only }\end{array}$ \\
\hline Evangelical & $\begin{array}{c}-6.228 * * * \\
(2.107)\end{array}$ & $\begin{array}{l}-0.678 \\
(1.692)\end{array}$ & $\begin{array}{l}-3.676 * * \\
(1.568)\end{array}$ & $\begin{array}{l}-4.029 \\
(2.944)\end{array}$ \\
\hline Other Christian & $\begin{array}{l}3.133^{*} \\
(1.594)\end{array}$ & $\begin{array}{l}2.800^{*} \\
(1.626)\end{array}$ & $\begin{array}{l}-1.182 \\
(1.744)\end{array}$ & $\begin{array}{l}-1.399 \\
(2.137)\end{array}$ \\
\hline Jewish & $\begin{array}{c}0.542 \\
(2.157)\end{array}$ & $\begin{array}{c}3.542 \\
(3.927)\end{array}$ & $\begin{array}{l}-3.066 \\
(2.169)\end{array}$ & $\begin{array}{l}-6.075^{* *} \\
(2.970)\end{array}$ \\
\hline Other religion & $\begin{array}{c}-5.928 * * * \\
(1.443)\end{array}$ & $\begin{array}{c}-4.562 * * * \\
(1.705)\end{array}$ & $\begin{array}{l}-1.580 \\
(1.840)\end{array}$ & $\begin{array}{l}-1.679 \\
(2.639)\end{array}$ \\
\hline $\begin{array}{l}\text { Do not belong to any voluntary } \\
\text { associations }\end{array}$ & $(0.793)$ & (1.137) & $(0.682)$ & (1.079) \\
\hline Region of origin: & & & & \\
\hline Western Europe & $\begin{array}{l}-0.161 \\
(1.173)\end{array}$ & $\begin{array}{c}0.287 \\
(1.381)\end{array}$ & $\begin{array}{l}-1.632 \\
(1.689)\end{array}$ & $\begin{array}{l}-1.115 \\
(2.112)\end{array}$ \\
\hline Eastern Europe & $\begin{array}{c}0.206 \\
(1.333)\end{array}$ & $\begin{array}{c}0.585 \\
(1.750)\end{array}$ & $\begin{array}{l}-3.339 * \\
(1.895)\end{array}$ & $\begin{array}{l}-5.850 * * \\
(2.419)\end{array}$ \\
\hline South Asia & $\begin{array}{c}2.326 \\
(2.181)\end{array}$ & $\begin{array}{c}3.204 \\
(2.025)\end{array}$ & $\begin{array}{l}-6.793 * * * \\
(2.599)\end{array}$ & $\begin{array}{l}-6.776^{* *} \\
(2.809)\end{array}$ \\
\hline East Asia & $\begin{array}{l}3.604 * * \\
(1.780)\end{array}$ & $\begin{array}{l}4.805 * * \\
(1.939)\end{array}$ & $\begin{array}{l}-3.399 * \\
(1.907)\end{array}$ & $\begin{array}{l}-0.931 \\
(2.462)\end{array}$ \\
\hline South-East Asia & $\begin{array}{c}1.689 \\
(1.800)\end{array}$ & $\begin{array}{l}2.167 \\
(2.180)\end{array}$ & $\begin{array}{l}-3.146 \\
(2.173)\end{array}$ & $\begin{array}{l}-3.358 \\
(2.198)\end{array}$ \\
\hline Latin America & $\begin{array}{l}-0.350 \\
(1.254)\end{array}$ & $\begin{array}{c}1.958 \\
(1.337)\end{array}$ & $\begin{array}{l}-3.486^{*} \\
(1.946)\end{array}$ & $\begin{array}{l}-4.325^{* *} \\
(2.105)\end{array}$ \\
\hline Caribbean & $\begin{array}{c}5.074 \\
(3.626)\end{array}$ & $\begin{array}{l}6.966 * * \\
(3.273)\end{array}$ & $\begin{array}{l}-1.335 \\
(2.248)\end{array}$ & $\begin{array}{l}-2.089 \\
(2.207)\end{array}$ \\
\hline Middle East & $\begin{array}{l}-4.865 \\
(3.665)\end{array}$ & $\begin{array}{l}-4.951 \\
(3.539)\end{array}$ & $\begin{array}{c}-9.009 * * * \\
(2.378)\end{array}$ & $\begin{array}{l}-7.424 * * \\
(3.098)\end{array}$ \\
\hline Ever been victim of hate crime & $\begin{array}{c}0.858 \\
(1.075)\end{array}$ & $\begin{array}{c}2.544 \\
(1.742)\end{array}$ & $\begin{array}{l}-1.260 \\
(1.153)\end{array}$ & $\begin{array}{l}-2.824 * \\
(1.686)\end{array}$ \\
\hline $\begin{array}{l}\text { Someone I know has been a victim of } \\
\text { a hate crime }\end{array}$ & $\begin{array}{l}0.605 \\
(0.736)\end{array}$ & $\begin{array}{l}-0.210 \\
(0.999)\end{array}$ & $\begin{array}{c}1.436 \\
(0.877)\end{array}$ & $\begin{array}{c}0.844 \\
(1.221)\end{array}$ \\
\hline Years as US citizen & & $\begin{array}{l}-0.0153 \\
(0.0273)\end{array}$ & & $\begin{array}{c}0.0191 \\
(0.0301)\end{array}$ \\
\hline Constant & $\begin{array}{c}8.350 * * * \\
(2.447)\end{array}$ & $\begin{array}{c}10.37 * * \\
(4.659)\end{array}$ & $\begin{array}{c}2.307 \\
(2.412)\end{array}$ & $\begin{array}{c}9.524 * * \\
(4.234)\end{array}$ \\
\hline
\end{tabular}




\begin{tabular}{lcccc}
\hline & $(1)$ & $(2)$ & $(3)$ & $(4)$ \\
\hline \hline & FM Amount & $\begin{array}{c}\text { FM Amount: } \\
\text { Immigrants } \\
\text { Only }\end{array}$ & SM Amount & $\begin{array}{c}\text { SM Amount: } \\
\text { Immigrants } \\
\text { Only }\end{array}$ \\
\hline Observations & \multicolumn{5}{c}{$\begin{array}{c} \\
\text { R-squared }\end{array}$} & 184 & 81 & 2,997 & 1,437 \\
Overall F statistic & 0.373 & 0.630 & 0.445 & 0.438 \\
F statistic p-value & 5.84 & 3.16 & 79.12 & 37.86 \\
& 0.0 & 0.0002 & 0.0 & 0.0
\end{tabular}

Robust standard errors in parentheses, clustered by subject. Treatment N-N is the reference group in columns 1 and 3. Treatment I-N is the reference group in column 2, and Treatment N-I is the reference group in column 4. North America is the reference group for region of origin, and No Religion is the reference group for religion.

$* * * \mathrm{p}<0.01, * * \mathrm{p}<0.05, * \mathrm{p}<0.1$ 